\title{
IMPLEMENTASI PASAL 86 AYAT (4) PERATURAN MENTERI KOPERASI DAN USAHA KECIL DAN MENENGAH NOMOR 09 TAHUN 2018 TENTANG KEWAJIBAN PENGESAHAN PENGURUS BARU KOPERASI DI KOTA MALANG
}

\author{
Larasati Trisnayani, Sihabudin, Herman Suryokumoro \\ Magister Kenotariatan Fakultas Hukum Universitas Brawijaya \\ Jl. MT. Haryono, Nomor 169. Malang \\ Email: larasatitrisnayani@yahoo.com
}

Abstract

The appointment of new board member in a cooperative must be notified and approved by the official or Ministry of Cooperatives and MSME (Micro, Small and Medium Enterprises) as stated in the Article 86 Clause (4), the 2018 Regulation of the Ministry of Cooperatives and MSME Number 09 regarding the Obligation to Ratify the Cooperative's New Board Member. The lack of information dissemination on this case causes differences among the cooperatives in its implementation. This study identifies and analyzes the implementation of the aforementioned regulation among cooperatives in Malang City. This research uses empirical juridical method with qualitative empirical approach. The result concludes that the implementation of the regulation is not effectively done in Malang. This is due to the inflexibility of the legal aspects, the law enforcers, as well as the facilities and infrastructure.

Pergantian pengurus baru Koperasi harus dilaporkan ke Dinas atau Kementerian Koperasi dan UMKM untuk mendapatkan persetujuan, sesuai Pasal 86 ayat(4) Peraturan Menteri Koperasi dan UMKM RI Nomor 09 Tabun 2018 Tentang Kewajiban Pengesahan Pengurus Baru Koperasi (selanjutnya akan disebut Permenkop dan UKM). Kurangny a sosialisasi informasi peraturan tersebut berakibatperbedaan antar koperasi melaksanakan peraturan tersebut. Tujuan penelitian ini adalah mengidentifikasi dan menganalisis pelaksanaan Pasal 86 ayat(4) Permenkop dan UKM Nomor 09 Tabun 2018 pada Koperasi di lingkungan Kota Malang. Jenis 
penelitian yang digunakan adalab yuridis empiris dengan metodependekatan Empiris Kualitatif. Berdasarkan hasilpenelitian diperoleh kesimpulan pelaksanaan peraturan tersebut di Kota Malang berjalan tidak efektif dikarenakan aspek bukumnya, aparat। penegak hukumnya serta sarana-prasarana yang sulit berubah.

Keywords: Enforcement, Ratification, Board Member, Cooperative

\section{Pendahuluan}

"Koperasi" berasal dari kata “co-operation” yaitu kerjasama. Setiap anggota mempunyai tugas dan tanggung jawab operasional koperasi pun memiliki hak suara sama saat pengambilan keputusan. Koperasi yaitu badan usaha atau organisasi ekonomi dengan kepemilikan dan pengoperasian orang-seorang demi kepentingan bersama. ${ }^{1}$

Struktur "koperasi” di Indonesia dapat dibagi berdasarkan perangkat organisasi koperasi, yaitu rapat anggota, pengurus dan pengawas. Pengurus koperasi yaitu orang yang ditunjuk anggota koperasi dalam RAT (Rapat Anggota Tahunan) koperasi, dengan lama masa jabatan paling panjang lima tahun sesuai dengan anggaran koperasi. seseorang yang terpilih menjabat pengurus yaitu seseorang yang diyakini mempunyai kemampuan mengelola organisasi “koperasi”. Dengan terpilih menjabat pengurus "koperasi" maka orang tersebut wajib bertanggung jawab terhadap kepercayaan yang dimandatkan oleh anggota "koperasi”. Di luar kemampuan serta keterampilan yang dipunyai oleh pengurus "koperasi" dari sisi pengalaman maupun latar belakang pendidikan ataupun pekerjaan, organisasi "koperasi" juga berpengaruh terhadap kinerja pengurus yang menjabat.

Penggerak "koperasi" (pengurus serta karyawan) menjabat sesuai porsi tugas dan keahlian yang dimiliki. Pengurus yang membuat kebijakan, di lain hal karyawan yang melaksanakan kebijakan itu. Kebijakan yang diambil pengurus yaitu kebijakan yang akan membuat unsur "koperasi" lebih aktif dan maju. Koperasi tidak cuma bersaing dengan sesama koperasi melainkan pun dengan badan usaha lain, oleh karena itu "koperasi" membutuhkan pengurus yang memiliki sumber daya baik, cakap berkomunikasi pada sesama pengurus ataupun anggota pun memiliki pengetahuan tentang "perkoperasian". Pengurus "koperasi” dipilih dari kalangan dan oleh anggota dalam suatu rapat anggota (selanjutnya akan disebut RA). ${ }^{2}$ Sepertiga dari anggota pengurus "koperasi" memungkinkan ditunjuk dari orang selain anggota "koperasi", diluar itu sebesar dua pertiga wajib berasal dari anggota "koperasi". Ada saatnya RA tidak berhasil menunjuk seluruh anggota

1 Hendrajogi, Koperasi: Azas-azas Teori dan Praktek (Jakarta: Raja Grafindo Persada, 1997), h.51.

2 Dahlan Djazh, Pengetahuan Koprasi (Jakarta: Balai Pustaka, 1980), h.162-163. 
Pengurus dari kalangan anggotanya. ${ }^{3}$ Contohnya, terjadi apabila calon dari kalangan anggotanya tidak mempunyai komitmen yang dibutuhkan untuk memimpin koperasinya, tetapi faktanya yang dapat menyanggupi syarat yaitu orang yang bukan anggota ataupun belum menjadi anggota "koperasi" (sudah dilayani "koperasi" akan tetapi belum resmi meminta menjadi anggota). ${ }^{4}$ Sesuai UU No 25 Tahun 1992 Tentang Perkoperasian pengurus berasal dari anggota, apabila diperlukan dapat menunjuk manajer untuk membantu pengelolaannya. Pengurus "koperasi" memiliki tanggung jawab langsung kepada RA. Tugas dan kewajiban pengurus "koperasi" yaitu memimpin organisasi dan usaha "koperasi" serta mewakilinya di muka dan di luar pengadilan sesuai dengan keputusan-keputusan RA.

Managemen "koperasi" terdiri dari RA, pengurus, pengawas dan pengelola yaitu tim managemen yang ditunjuk dan diberhentikan oleh Pengurus, demi melakukan tugas operasional dalam bidang usaha. Hubungan managing director (pengelola usaha) terhadap pengurus "koperasi" yaitu hubungan pekerjaan berdasarkan perikatan yang memiliki rupa perjanjian atau kontrak kerja. Pada dasarnya managemen "koperasi" mempunyai fungsi yaitu perencanaan,pengorgan isasian,pengarahan,kepemimpinan serta pengawasan. Secara demikian "koperasi" dapat melengkapi kebutuhan bersama tiap anggotanya serta memenuhi tujuannya yaitu meningkatkan perekonomian masyarakat. Menurut Prof. Ewell Paul Roy yang menyebutkan managemen koperasi menyertakan empat unsur: pengurus, manajer, karyawan serta anggota. Tugas dari manajer beliau wajib dapat memunculkan keadaan dalam rangka peningkatan karyawannya secara produktifitas. Karyawan sebagai penghubung anggota pelanggan serta managemen. ${ }^{5}$ Di sisi lain, Suharsono Sagir mengatakan, managemen lembaga "koperasi" wajib menuju terhadap managemen partisipatif ssesuai karakteristik "koperasi". Hal tersebut harus meliputi keterbukaan serta kebersamaan, agar tiap anggota koperasi dapat mempunyai semangat tanggung jawab secara bersama di dalam organisasi "koperasi".

Regulasi tentang tugas dan fungsi alat kelembagaan "Koperasi” selain diatur pada Undang-Undang No 25 Tahun 1992 Tentang Perkoperasian diatur juga pada Anggaran Dasar "Koperasi" (yang untuk selanjutnya akan disebut AD) ditetapkan saat pendiriannya. ${ }^{6}$ Saat pendirian suatu koperasi diperlukan atau menggunakan suatu akta Notaris yang berkekuatan hukum yang kuat. Kekuatan hukum inilah yang menjadi dasar kegiatan perkoperasian, supaya mempunyai perlindungan

3 Hans, Prinsip-prinsip Koperasi dan Undang-undang Koperasi (Jakarta: Direktorat Jenderal Koperasi, 1980), h.43.

4 Hans, Prinsip-prinsip Koperasi dan Undang-undang Koperasi,... h.45.

5 Hendrajogi, Koperasi: Azas-azas Teori dan Praktek,... h.54.

6 Undang-Undang Nomor 25 Tahun 1992 Tentang Perkoperasian. 
bagi lembaga dan pengurusnya. ${ }^{7}$ Sesuai dengan AD "Koperasi" tiap tiga atau lima tahun sekali dilakukan pergantian pengurus, hal ini dapat terjadi akibat pergantian waktu sebab terdapat pengurus yang melakukan pengunduran diri. ${ }^{8}$ Pengurus "koperasi" ditunjuk dari kalangannya serta oleh anggota saat kegiatan RA. . Sepertiga dari pengurus "koperasi" bisa ditunjuk dari orang bukan anggota koperasi, namun dua pertiga sisanya wajib berasal dari anggota "koperasi". Namun, ada saatnya RA yang dilakukan tidak dapat menunjuk semua Pengurus yang berasal dari anggotanya. ${ }^{10}$ Sehubungan dengan persoalan ini, pergantian yang berkaitan dengan pengurus wajib dilaporkan ke Dinas atau Kementerian Koperasi dan UMKM (selanjutnya disebut Kemenkop dan UKM) dengan tujuan dicatat atau mendapatkan persetujuan. Hal ini sesuai dengan yang dinyatakan dalam Pasal 86 ayat (4) Permenkop RI No 09 Tahun 2018 Tentang Kewajiban Pengesahan Pengurus Baru Koperasi yang mengatakan:

Pergantian susunan dan nama anggota Pengurus Koperasi dilaporkan kepada Kementerian Koperasi dan UKM dan/atau Dinas Provinsi, Dinas Kabupaten/ Kota sesuai dengan wilayah keanggotaannya dengan dilengkapi dokumen berita acara rapat perubahan pengurus; b) fotokopi akta dan keputusan pendirian dan /atau akta dan keputusan perubahan sebelumnya; c) daftar hadir rapat Anggota Perubahan Pengurus; d) buku daftar anggota koperasi; e) fotokopi KTP pengurus; serta f) berita acara serah terima jabatan.

Tujuan didaftarkannya pergantian pengurus kepada Kemenkop dan UKM dan/atau Dinas Provinsi (selanjutnya disebut Dinkop Provinsi), Dinas Kabupaten / Kota (selanjutnya disebut Dinkop Kabupaten / Kota) berdasarkan dengan wilayahnya adalah untuk menjamin hubungan antara Koperasi dengan mitra bisnisnya, contohnya Bank. Namun, ada koperasi yang mengalami kesulitan untuk melaksanakan Pasal 86 ayat (4) Permenkop dan UKM RI tersebut. Hal ini mengakibatkan kerugian bagi "Koperasi" yang melakukan pergantian pengurus.

Kesulitan dalam melaksanakan Pasal 86 ayat (4) Permenkop dan UKM RI tersebut diperkuat dengan adanya kasus Koperasi Lavalete yang melakukan Rapat Anggota Tahunan (selanjutnya disebut RAT) yang biasanya hanya dibuat dalam bentuk di bawah tangan tetapi pada rapat selanjutnya RAT tersebut dibuat dalam akta otentik yang dibuat oleh Pejabat yang berwenang yaitu Notaris. Pada

7 Kepmen Negara Koperasi dan UKM Menengah Nomor 98/KEP/M.KUKM/ IX Tahun 2004 Tentang Notaris Sebagai Pembuat Akta Koperasi.

8 Permenkop dan UKM Nomor 01/Per/M.KUKM/I/2006 Tentang Petunjuk Pelaksanaan Pembentukan,Pengesahan Akta Pendirian dan Pembubaran AD Koperasi.

9 Dahlan Djazh,Pengetabuan Koprasi,... h.36.

10 Hans,Prinsip-prinsip Koperasi dan Undang-undang Koperasi,... h.56. 
saat akan dilaporkan pada sistem Kementerian Koperasi yaitu AHU (Administrasi Hukum Umum) nama pengurus baru tidak muncul dan yang muncul adalah tetap nama pengurus sebelumnya, setelah dilaporkan ternyata pelaporan perubahan pengurus tersebut cukup dilaporkan pada Dinas Koperasi setempat. Akan tetapi, Dinas Koperasi setempat juga menolak dengan alasan bahwa tidak mempunyai akses untuk dapat melakukan perubahan pengurus tersebut pada sistem yang tersedia. Hal ini menjadi kendala pada saat pengurus baru Koperasi Lavalete akan mengajukan kredit pada Bank Jatim, pengajuan kredit tersebut ditolak karena pada saat Bank Jatim melakukan pengecekan pada sistem yang muncul adalah nama pengurus lama dan pengurus yang baru dianggap tidak berwenang untuk melakukan pengajuan kredit. Hal ini menyebabkan kegiatan usaha Koperasi Lavalete tidak bisa berjalan seperti semula dan akhirnya terhenti. Namun, apakah bukti pelaporan pergantian pengurus koperasi tersebut harus dibuktikan pada sistem saja atau cukup dengan surat keterangan Kemenkop dan UKM dan / atau Dinkop Provinsi, Dinkop Kabupaten atau Kota berdasarkan wilayahnya dan apakah "koperasi" di lingkungan Kota Malang mengalami kesulitan dalam melaksanakan pelaporan pergantian pengurusnya.

Berdasarkan pemaparan diatas akan sangat menarik untuk diteliti lebih lanjut bagaimana Pelaksanaan Pasal 86 ayat (4) Permenkop dan UKM RI tersebut dalam kaitannya pelaksanaan pasal tersebut di lingkungan Koperasi Kota Malang.

\section{Metode Penelitian}

Jenis penelitian yang digunakan adalah yuridis empiris. ${ }^{11}$ Dengan metode pendekatan Empiris Kualitatif yang fokus kepada kasus Koperasi Karyawan Rumah Sakit Lavallette berdasarkan Pelaksanaan Pasal 86 ayat (4) Permenkop dan UKM RI Tentang Kewajiban Pengesahan Pengurus Baru Koperasi.

Jenis sumber data di dalam penelitian ini yaitu sumber data primer ialah penelitian ini didapat atau diperoleh dari hasil kegiatan wawancara, pendapat dan pernyataan dari narasumber langsung yang terkait dengan Pelaksanaan Pasal 86 ayat (4) Peraturan Menteri Koperasi dan Usaha Kecil dan Menengah Republik Indonesia Nomor 09 Tahun 2018 Tentang Kewajiban Pengesahan Pengurus Baru Koperasi pada Koperasi di lingkungan Kota Malang, sehingga nantinya dapat menjadi bahan analisa apakah dengan regulasi dan kebijakan-kebijakan yang terbaru dalam ranah Koperasi dapat memberikan jaminan kemanfaatan bagi masyarakat

11 Musyarrofa Rahmawati, Efektivitas Pembatasan Usia Perkawinan Berdasarkan UndangUndang Nomor 1 Tahun 1974 Tentang Perkawinan, JIPPK,Vol. 3 No.1 Tahun 2018, h. 100-105. 
setempat. Data primer diperoleh dari pihak-pihak terkait dengan permasalahan, yaitu: Dinkop sebagai instansi pemerintah yang berhak untuk menerima pelaporan pergantian susunan pengurus baru koperas serta Koperasi yang mengalami kesulitan dalam melaporkan pergantian susunan pengurus baru koperasi. Sedangkan sumber data sekunder diperoleh dari penelusuran: Kepustakaan seperti PDIH Fakultas Hukum Universitas Brawijaya Malang, Perpustakaan Pusat Universitas Brawijaya Malang, Perpustakaan Kota Malang, dan di Perpustakaan-perpustakaan lain yang dapat menunjang penelitian penulis; dokumen-dokumen lain yang mendukung; serta Penelusuran di internet.

Teknik pengumpulan data yang dipergunakan dalam penelitian tesis ini yaitu populasi dalam penelitian ini adalah semua pihak yang terkait dengan Pelaksanaan Pasal 86 ayat (4) Permenkop dan UKM RI Tentang Kewajiban Pengesahan Pengurus Baru Koperasi, meliputi Koperasi yang selama 2 tahun ini melakukan pergantian pengurus baru dan mengalami kesulitan dalam pelaporan pergantian pengurus baru pada pihak Dinkop, Kepala Koperasi, pengurus koperasi ataupun Kepala Sub Bagian Dinkop di Kota Malang yang melakukan pencatatan berkaitan dengan pelaporan pergantian sususan pengurus baru koperasi. Informan dalam kajian ini adalah Dinas Koperasi dan UKM, Pengurus Koperasi, Manager Koperasi dan Karyawan Koperasi di Kota Malang yang melakukan pengesahan pengurus baru Koperasi. Didukung data primer yaitu data yang didapat langsung dari sumber yang dituju, baik observasi, wawancara serta data sekunder yaitu peraturan perundangan yang berhubungan, buku yang berkaitan, jurnal ilmiah baik online maupun tidak online dan literature lainnya yang terkait. ${ }^{12}$

Teknik analisa data dalam penelitian ini, yaitu dengan kualitatif, dengan pengertian bahwa data-data yang dihasilkan akan memberikan gambaran yang sesuai dengan kenyataan yang ada. Pendekatan kualitatif merupakan suatu proses penelitian dan pemahaman yang berdasarkan pada metodologi yang menyelidiki suatu fenomena sosial dan masalah pada manusia. ${ }^{13}$ Untuk melakukan analisa data yang bersifat kualitatif ini peneliti mempergunakan analisa kualitatif, yaitu data yang diperoleh dipilih dan disusun secara sistematis kemudian dianalisa secara kualitatif dengan menggunakan teori-teori dan peraturan perundang-undangan berkaitan dengan permasalahan yang dibahas sehingga mendapatkan hasil analisa tentang pelaksanaan Pasal 86 ayat (4) Peraturan Menteri Koperasi dan Usaha Kecil dan Menengah Republik Indonesia Nomor 09 Tahun 2018 Tentang Kewajiban

12 Retno Mumpuni, Peran Serta Ondofolo Dalam Ganti Rugi Tanah Untuk Kepentinga Umum Yang Berkeadilan, JIPPK,Vol.2 No. 1 Tahun 2017,h. 64-74.

13 Amiruddin dan Zainal Asikin, Pengantar Metode Penelitian Hukum (Jakarta: Raja GrafindoPersada, 2004), h.167. 
Pengesahan Pengurus Baru Koperasi pada Koperasi di lingkungan Kota Malang dan nantinya akan memberikan gambaran mengenai dapat atau tidaknya regulasiregulasi terbaru di bidang hukum Koperasi memberikan kepastian hukum bagi pengurus baru Koperasi, yang pada tahap selanjutnya data-data tersebut akan disusun sebagai sebuah karya tulis ilmiah dalam bentuk tesis atau tugas akhir.

\section{Pembahasan}

Pelaksanaan Pasal 86 ayat (4) Permenkop dan UKM RI Tentang Kewajiban Pengesahan Pengurus Baru Koperasi pada Koperasi Di Lingkungan Kota Malang

Ketika berkeinginan mengukur sejauh apa efektfitas aturan hukum, maka pertama kita harus mengukur sejuh apa aturan hukum tersebut itu dipatuhi ataupun tidak dipatuhi, jelas, jikalau aturan tersebut dapat dipatuhi oleh mayoritas dari target yang telah dijadikan sasarannya, dengan begitu dapat dikatakan bahwa aturan tersebut telah efektif.

Sebuah aturan tersebut haruslah dalam keadaan valid dahulu baru dapat dilihat apakah aturan tersebut sudah efektif. Supaya hukum tersebut dapat menjadi valid, aturan tersebut haruslah dapat diterima oleh masyarakat. Pun sebaliknya, demi dapat diterapkan pada suatu masyarakat, demikian peraturan wajib merupakan hukum valid atau legitimate. Berjalan efektif mempunyai arti yaitu orang sungguhsungguh berbuat sesuai norma hukum, sebagaimanapun wajib mengikat, agar norma-norma itu benar-benar dapat dipatuhi dan dijalankan. ${ }^{14}$

Suatu aturan yang valid belum pasti adalah suatu kaidah hukum yang efektif. Berkaitan dengan ini, suatu validitas norma merupakan hal yang termasuk ke dalam yang seharusnya (das solen), sedangkan efektifitas suatu norma merupakan sesuatu dalam kenyataan (das sein). Tentang keefektifan berlakunya suatu norma hukum, maka terdapat berbagai variasi pandangan sesuai aliran dan paham yang dianutnya. Bagi kaum positivism atau penganut teori hukum dasar (grundnorm), tidak banyak menjadi soal karena suatu norma hukum yang valid dapat dipaksakan berlakunya karena diikuti dengan sanksi-sanksi hukum bagi yang melanggarnya. ${ }^{15}$

Apabila efektifitas perundangan yang dikaji, kita dapat menyuarakan efektifitas suatu perundangan, tergantung pada beberapa faktor antara lain: pengetahuan mengenai substansi perundang-undangan; cara mendapatkan pengetahuan tersebut; instansi berkaitan dengan ruang lingkup perundangan di dalam masyarakatnya; serta bagaimana proses munculnya perundangan yang tidak boleh diterbitkan


14 Munir Fuady, Teori-teori Besar Dalam Ilmu Hukum, (Jakarta: Kencana, 2013,),h.116.

15 Munir Fuady, Teori-teori Besar Dalam Ilmu Hukum,... h. 376-378. 
undang-undang sapu mempunyai kualitas kurang baik dan tidak sesuai dengan diperlukan masyarakatnya. ${ }^{16}$

Taatnya orang bermasyarakat sesuai dengan harapan pembuat UndangUndang, Lawrence M. Friedman mengatakan bahwa:

"compliance is, in other words, knowing conformity with a norm or command, a deliberate instance of legal behavior that has bens toward the legal act that evoked it. Compliance and deviance are two poles of a continuum. Or the legal behavior frustrates the goals of a legal act, but falls short of noncompliance or, as the case may be, legal culpability." ${ }^{\prime 7}$

Berdasarkan pendapat Lawrence M. Friedman tersebut bahwa pengaruh hukum pada perilaku atau sikap tindak, dapat dikelompokkan sebagai kepatuhan, ketidakpatuhan maupun pengelakan serta penyimpangan. Konsep tersebut berkaitan dengan hukum yang berisikan larangan atau suruhan.

Lawrence M. Friedman menyatakan "tiap setiap sistem hukum terdapat 3(tiga) unsur, yaitu: ${ }^{18}$

1. Substansi Hukum: disebut sebagai sistem substansial yang dapat juga menentukan dapat atau tidaknya hukum itu dilaksanakan. ${ }^{19}$

2. Struktur Hukum/Pranata Hukum : Dalam hal ini adalah sebagai sistem Struktural yang mampu menentukan dapat tidaknya aturan diterapkan dengan lancar. Wewenang lembaga penegak hukum dipastikan dalam UU. Sehingga untuk melakukan tanggung jawab serta tugasnya dapat terbebas dari pengaruh kekuasaan pemerintah maupun pengaruh lain. ${ }^{20}$

3. Budaya Hukum: Kultur hukum merupakan suasana pemikiran sosial serta kekuatan sosial yang dapat menentukan bagaimana hukum diterapkan, dihindari atau disalahgunakan. Budaya hukum sangat erat kaitannya dengan kesadaran hukum masyarakat. ${ }^{21}$ Budaya serta Masyarakat ialah sebuah fenomena yang sulit untuk dipisahkan. Antar unsur budaya terjalin satu sama lain dan mempengaruhi satu sama lain serta perubahan hanya satu unsur dapat menimbulkan perubahan pada unsur lainnya. Demikian tidak dapat dilepaskan sama sekali dari hubungannya dengan proses sosial yang terjadi dalam suatu masyarakat sebagai hasil dari kontruksi sosial. ${ }^{22}$

16 Munir Fuady, Teori-teori Besar Dalam Ilmu Hukum,... h. 376-378.

17 Siswantoro Sunarso, Penegakan Hukum Psikotropika Dalam Kajian Sosiologi Hukum (Jakarta: Raja Grafindo Persada, 2010), h. 88.

18 Siswantoro Sunarso, Penegakan Hukum Psikotropika Dalam Kajian Sosiologi Hukum,... h. 11.

19 Siswantoro Sunarso, Penegakan Hukum Psikotropika Dalam Kajian Sosiologi Hukum,... h. 11.

20 Siswantoro Sunarso, Penegakan Hukum Psikotropika Dalam Kajian Sosiologi Hukum,... h. 13.

21 Siswantoro Sunarso, Penegakan Hukum Psikotropika Dalam Kajian Sosiologi Hukum,... h. 15.

22 Khudzaifah Dimyati, Teorisasi Hukum (Surakarta: Muhammadiyah University Press, 2004), h.107. 
Ketiga unsur sistem hukum tersebut saling berkaitan satu dengan yang lainnya serta tidak dapat terpisahkan. Di dalam pelaksanaan wajib terwujud hubungan saling dukung diantara ketiganya demi tercipta suasana hidup aman, tertib serta damai.

Disimpulkan bahwa suatu tujuan dapat dinyatakan efektif bila tujuan tersebut sesuai yang diinginkan. Jadi tujuan yang diinginkan adalah pencapaian dari tujuan tersebut sehingga berlaku efektif. Bila tujuan yang dimaksud ialah tujuan yang berasal dari pemerintah maka proses tercapainya tujuan tersebut adalah keberhasilan menjalankan program atau kegiatan menurut fungsi, wewenang serta tugas dari pemerintah.

Sedangkan, teori efektifitas hukum menurut Soerjono Soekanto adalah bahwa efektif atau tidaknya suatu hukum ditentukan oleh 5 (lima) faktor, yaitu :23

1. Faktor hukumnya sendiri (UU)

Faktor hukum berfungsi untuk kepastian, keadilan serta kemanfaatan. Praktik terselenggaranya hukum di lapangan ada saatnya terjadi pertentangan antara kepastian hukum serta keadilan. Kepastian Hukum bersifat konkret berwujud nyata, di sisi lain keadilan mempunyai sifat abstrak hingga ketika hakim memutus suatu perkara dengan cara diterapkan UU saja, maka ada saatnya nilai keadilan tersebut tidak terpenuhi. Demikian ketika memandang persoalan terkait hukum paling tidak keadilan adalah prioritas utama. Sebab hukum tidak semata dipandang hukum tertulis saja.

2. Faktor penegak hukum (Pihak-pihak yang membentuk ataupun menerapkan hukum)

Faktor penegak hukum dalam berjalannya hukum, mentalitas ataupun kepribadian penegak hukumnya menjalankan peranan penting, bila aturan sudah baik, akan tetapi kualitas petugas tidak cukup baik, maka terdapat masalah. Sejauh ini ada kecenderungan kuat di kelompok masyarakat untuk mendeskripsikan hukum sebagai penegak hukumnya, yang berarti hukum identik dengan tingkah laku nyata penegak hukumnya. Namun sayang dalam menjalankan wewenangnya sering muncul persoalan akibat perlakuan yang dipandang melebihi wewenangnya yang dicap menghilangkan wibawa serta citra penegak hukum. Hal ini diakibatkan kualitas rendah dari aparat penegak hukum tersebut.

3. Faktor sarana atau fasilitas (Mendukung penegakan hukum)

Faktor ini meliputi perangkat lunak serta keras. Menurut Soerjono

23 Soerjono Soekanto, Faktor-Faktor Yang Mempengarubi Penegakan Hukum (Jakarta: Rajawali Pers, 2008), h. 54. 
Soekanto, para penegak hukum tidak mungkin bekerja dengan baik, bila tidak tercukupi alat komunikasi serta kendaraan yang memenuhi. Oleh sebab itu, sarana fasilitas memiliki peranan yang amat penting dalam penegakan hukumnya. Tiada sarana fasilitas tersebut, tak mungkin penegak hukum menyesuaikan peranan yang harusnya dengan peranan yang aktual.

4. Faktor masyarakat (Lingkungan dimana hukum tersebut berlaku atau diterapkan)

Setiap kelompok masyarakat atau kelompok sedikit banyaknya mempunyai kesadaran hukum. Persoalan yang muncul adalah taraf kepatuhan hukum, yaitu kepatuhan hukum yang besar, cukup, atau kurang. Terdapat derajat patuhnya hukum masyarakat terhadap hukum, merupakan salah satu pengukur berfungsinya hukum berkaitan.

5. Faktor kebudayaan (Hasil karya, cipta dan rasa yang didasarkan pada karsa manusia di dalam pergaulan hidup)

Budaya pada dasarnya meliputi nilai-nilai yang mendasari hukum yang berjalan, nilai yang merupakan konsepsi abstrak tentang apa yang dicap baik(hingga dituruti) dan apa yang dicap buruk (hingga dihindari). Dengan demikian, budaya Indonesia merupakan dasar hukum adat berlaku. Selain itu, berlaku pula hukum tertulis (UU), yang dibuat golongan tertentu dalam masyarakat yang mempunyai kewenangan serta kuasa untuk itu. Hukum UU tersebut wajib mampu memperlihatkan nilai dasar hukum adat, sehingga hukum UU tersebut mampu berlaku secara aktif.

Lima faktor di atas saling bergandengan dengan eratnya, sebab menjadi hal pokok dalam ditegakkannya hukum, juga menjadi tolok ukur efektifitas penegakan hukum. Dari kelima faktor penegakan hukum tersebut faktor penegakan hukumnya sendiri merupakan titik sentral. Hal ini akibat oleh UU disusun penegak hukum, penerapannya juga dijalankan oleh penegak hukum dan penegakan hukum sendiri pula merupakan panutan seluruh masyarakat.

Ditinjau dari beberapa pendapat para ahli hukum di atas, pendapat Lawrence M. Friedman dan Soerjono Soekanto tentang faktor-faktor yang mempengaruhi efektivitas hukum hampir sama. Pada intinya yang paling bisa diterapkan dalam kehidupan modern seperti sekarang ini adalah keefektifan norma hukum dapat ditinjau apabila norma hukum tersebut dapat diterima oleh masyarakat sebagai suatu kebijakan yang memberikan kemanfaatan, ketertiban, dan kedamaian serta di dalam norma hukum tersebut terdapat sanksi-sanksi yang tegas sebagai alat pengatur bagi yang melanggarnya. 
Dalam konteks penelitian hukum pelaksanaan Pasal 86 ayat (4) Permenkop dan UKM RI Tentang kewajiban pengesahan pengurus baru koperasi di Kota Malang, teori efektivitas digunakan untuk menganalisa sejauh mana pelaksanaan pengaturan tentang kewajiban pengesahan pengurus baru koperasi dalam Permenkop dan UKM RI dalam kehidupan masyarakat Indonesia pada umumnya dan masyarakat Kota Malang secara khusus. Sedangkan, teori efektifitas yang akan digunakan dalam penelitian ini adalah yang dikemukakan oleh Soerjono Soekanto, karena dalam setiap sistem hukum terdapat 5 (lima) faktor yaitu faktor hukumnya sendiri, faktor penegak hukum, faktor sarana atau fasilitas, faktor masyarakat dan faktor kebudayaan. Selanjutnya, akan dianalisa meliputi Pasal 86 ayat (4) Permenkop dan UKM RI sebagai faktor hukum, dinas koperasi sebagai penegak hukum dan pengurus koperasi sebagai masyarakat. Pelaksanaan Pasal 86 ayat (4) Permenkop dan UKM RI Tentang Kewajiban Pengesahan Pengurus Baru Koperasi tidak berjalan efektif di Kota Malang. Banyak hal di lapangan yang menyebabkan ketentuan tersebut tidak terlaksana apabila dikaji menurut teori Soerjono Soekanto, yaitu: ${ }^{24}$

1. Faktor hukumnya sendiri (UU) ${ }^{25}$, Peraturan Pemerintah Republik Indonesia Nomor 24 Tahun 2018 Tentang Pelayaan Perizinan Berusaha Terintegrasi Secara Elektronik (selanjutnya disebut PP RI OSS) berbenturan dengan isi dari Pasal 86 ayat (4) Permenkop dan UKM RI Tentang Kewajiban pergantian nama pengurus baru Koperasi yang sebelumnya hanya didaftarkan kepada Kemenkop dan UKM dan / atau Dinkop Provinsi, Dinkop Kabupaten/ Kota sesuai dengan wilayahnya saja, saat ini menjadi harus didaftarkan pula pada sistem OSS. ${ }^{26}$

2. Faktor penegak hukum (Pihak yang membentuk ataupun menerapkan hukum), di dalam prakteknya menimbulkan ketidaksamaan perlakuan pihak perbankan dalam syarat memberikan kredit pada koperasi, tidak semua Bank dan Koperasi di Kota Malang menerapkan dan melaksanakan syarat yang sama.

3. Faktor sarana atau fasilitas (Yang mendukung penegakan hukum), salah satu contoh perangkat lunak adalah sosialisai tentang peraturan tersebut. Sosialisasi terhadap Undang-Undang atau aturan baru yang rendah juga menjadi faktor pendukung sebagian besar koperasi berbeda-beda dalam melaksanakan pengesahan perubahan susunan pengurus baru Koperasi. Masalah perangkat keras dalam

24 Soerjono Soekanto, Faktor-Faktor Yang Mempengarubi Penegakan Hukum,... h. 56.

25 c, Politik Hukum Islam di Indonesia Studi terhadap Legislasi KHI, Jurnal Mimbar Hukum, No. 59 Th.XIV, Tahun 2003, h.74.

26 PP RI OSS. 
hal ini adalah sarana fisik yang berfungsi sebagai faktor pendukung.

4. Faktor masyarakat (Lingkungan hukum tersebut berlaku ataupun diterapkan), Koperasi yang mengajukan kredit pada Bank, namun Bank tersebut tidak meminta perubahan nama pengurus baru pada Koperasi pada sistem dan cukup dengan surat keterangan pergantian pengurus baru pada Koperasi. Maka, tentu saja mereka tidak akan mengurus perubahan nama pengurus baru pada Koperasi pada sistem. Lain halnya bagi Koperasi yang membutuhkan kredit pada Bank dan mendapatkan syarat pengajuan kredit termasuk syarat pergantian nama pengurus baru pada sistem pasti akan berusaha agar nama pengurus lamanya yang telah ada di sistem dapat tergantikan sesuai dengan nama pengurus barunya dan akan mengupayakan jalan lain termasuk meminta pengesahan atau bukti-bukti dari Dinas Koperasi Kota Malang.

5. Faktor kebudayaan (Hasil karya,cipta serta rasa didasarkan pada karsa manusia didalam pergaulanhidup), kebiasaan Koperasi yang berbeda-beda dalam melaksanakan Pasal 86 ayat (4) Peraturan Menteri Koperasi dan Usaha Kecil dan Menengah Republik Indonesia Nomor 09 Tahun 2018 Tentang Kewajiban Pengesahan Pengurus Baru Koperasi serta syarat yang berbeda dari tiap Bank untuk pengajuan kredit membuat hal ini menjadi kebiasaan yang berlaku.

Kebiasaan Koperasi yang berbeda-beda dalam melaksanakan Pasal 86 ayat (4) Permenkop dan UKM RI Tentang Kewajiban Pengesahan Pengurus Baru Koperasi serta syarat yang berbeda dari tiap Bank untuk pengajuan kredit membuat hal ini menjadi kebiasaan yang berlaku. Harus ada suatu sosialisasi sehingga membuat keseragaman pelaksaan Pasal 86 ayat (4) Permenkop dan UKM RI Tentang Kewajiban Pengesahan Pengurus Baru Koperasi.

Lima faktor di atas saling berhubungan erat, sebab menjadi halpokok dalam ditegakkannya hukum, juga menjadi tolok ukur efektifitas penegakan hukum. Dari kelima faktor penegakan hukum tersebut faktor penegakan hukumnya sendiri merupakan titik sentral. Hal ini akibat oleh UU disusun penegak hukum, penerapannya juga dijalankan oleh penegak hukum dan penegakan hukum sendiri pula merupakan panutan seluruh masyarakat.

Pemaparan di atas menunjukkan bahwa ketentuan tentang pelaksanaan Pasal 86 ayat (4) Permenkop dan UKM RI Tentang Kewajiban Pengesahan Pengurus Baru Koperasi di Kota Malang tidak berjalan efektif ditinjau dari aspek hukumnya, aparat/ penegak hukumnya, sarana dan prasarana, masyarakat dan budayanya. Terlebih tiga faktor pertama menjadi faktor dominan dalam memicu tidak efektifnya ketentuan kewajiban pengesahan susunan pengurus 
baru Koperasi. Hal ini mengurangi manfaat dari sistem yang sudah ada dan telah memakan banyak biaya. Padahal sesungguhnya sistem itu dapat dimanfaatkan untuk mengupdate berita terbaru maupun Undang-Undang dan peraturan yang akan semakin mendorong keaktifan kegiatan Koperasi.

Menurut dalil dalam Al-Quran perlindungan hukum bagi pengesahan pengurus baru Koperasi harus sesuai dengan dalil kemaslahan umat. Menurut Abdullah bin Abdul Muhsin al-Turky bahwa yang dimaksud dengan mashlahah ialah: "Sebuah sifat yang merupakan konsekuensi sebuah hukum berupa menggapai segala kemanfaatan bagi manusia dan juga menolak segala kerusakan dari mereka." ${ }^{27}$

Dengan demikian, seharusnya pengesahan pengurus baru Koperasi menurut Permenkop dan UKM RI Tentang Kewajiban Pengesahan Pengurus Baru Koperasi haruslah bermanfaat bagi pengurus Koperasi yang baru dan administrasi Koperasi sebagai badan hukum sehingga tidak mempersulit para pengurus Koperasi untuk melaksanakan kegiatan perekonomian Koperasinya.

Faktor Penyebab Koperasi Yang Melakukan Pergantian Pengurus Tidak Melakukan Pelaporan Sesuai Dengan Pasal 86 ayat (4) Permenkop dan UKM RI Tentang Kewajiban Pengesahan Pengurus Baru Koperasi Pada Koperasi di Lingkungan Kota Malang

Pelaksanaan Pasal 86 ayat (4) Permenkop dan UKM RI Tentang Kewajiban Pengesahan Pengurus Baru Koperasi di Kota Malang berjalan tidak efektif terutama dikarenakan aspek hukumnya, aparat/ penegak hukumnya dan sarana dan prasarana yang sulit untuk berubah.

Dalam konteks pelaksanaan Pasal 86 ayat (4) Permenkop dan UKM RI Tentang Kewajiban Pengesahan Pengurus Baru Koperasi di Kota Malang, rupanya hukum yang berkeinginan menimbulkan perubahan-perubahan dan suatu keadaan yang dicita-citakan belum terjadi. Padahal sesungguhnya cita-cita dari pengesahan susunan pengurus baru Koperasi adalah untuk mencegah terjadinya hal-hal yang tidak diinginkan, seperti kesulitan dalam mengajukan kredit pada Bank karena tidak dapat memenuhi syarat tentang pengesahan susunan pengurus baru Koperasi. Namun demikian, merubah pola pikir dan kebiasaan masyarakat tidaklah mudah.

Koperasi Kota Malang sebagaimana disebutkan sebelumnya, tidak mengetahui tentang berlakunya peraturan pengesahan susunan pengurus baru Koperasi. Namun, Koperasi Karyawan Rumah Sakit Lavallete melaksanakan pengesahan

27 Abdullah bin Abdul Muhsin al-Turky, Ushul Mazhab Imam Ahmad (Beirut: Muassasah al-Risalah, 1990), h. 459 
susunan pengurus baru Koperasi hingga sampai pada sistem. Hal ini disebabkan demi memenuhi syaat pengajuan kredit pada Bank.

Sedangkan, pada KPRI UM dan Koperasi Depag Basis tidak melakukan pendaftaran pada sistem dan hanya cukup dengan mendapatkan surat keterangan susunan pergantian pengurus baru Koperasi dari Dinas Koperasi dan UMKM. Kedua Koperasi tersebut merasa tidak perlu melakukan pendaftaran pada sistem karena pengajuan kredit yang mereka ajukan pada Bank tidak meminta persyaratan pengesahan pengurus baru Koperasi. Mengubah Koperasi untuk turut berperan aktif dan update tentang berita terbaru serta Undang-Undang dan peraturan tentang Koperasi bukan hal yang mudah. Perlu sosialisasi terus menerus untuk menggugah kesadaran Koperasi untuk selalu berperan aktif dan update akan pentingnya pengesahan susunan pengurus baru Koperasi untuk memperoleh kemudahan dalam melaksanakan kegiatan ekonomi atau bisnis Koperasinya, dengan melaksanakan peraturan yang sudah berlaku.

Meminimalisir Koperasi Yang Melakukan Pergantian Pengurus Tidak Melakukan Pelaporan Sesuai dengan Pasal 86 ayat (4) Permenkop dan UKM RI Tentang Kewajiban Pengesahan Pengurus Baru Koperasi pada Koperasi di Lingkungan Kota Malang

Koperasi sebagai sebuah Koperasi adalah sebuah salah satu badan usaha resmi yang berada di Indonesia. Di mana tujuannya adalah untuk mensejahterakan para anggotanya. Dalam hal ini, koperasi dibentuk di mana kegiatannya berdasarkan prinsip gerakan ekonomi kerakyatan. ${ }^{28}$ Koperasi dibangun untuk meningkatkan perekonomian masyarakat Indonesia dengan asas kekeluargaan dan mengedepankan prinsip gotong royong. Keberhasilan suatu Koperasi ditentukan oleh apakah Koperasi tersebut dapat mempertahankan atau memperluas jenis usahanya. Sehingga dapat menjadi Koperasi yang besar, langgeng serta mempunyai kesehatan secara ekonomi. Demikianlah hakikat dari sebuah Koperasi yaitu sehat secara ekonomi dan dapat mengembangkan usahanya.

Demi terwujudnya tujuan tersebut terkadang harus membuat Koperasi mengajukan kredit pada Bank. Keputusan untuk melakukan pengajuan kredit membutuhkan suatu pemikiran yang matang. Karena berhasil atau tidaknya pengajuan kredit dilihat dari kesanggupan Koperasi untuk melengkapi syaratsyarat yang diberikan oleh Bank yang akan memberikan kredit pada Koperasi tersebut. Sebuah Koperasi harus mampu untuk melengkapi syarat-syarat yang diberikan oleh Bank tersebut agar pemberian kredit oleh Bank dapat dilakukan secara cepat dan tidak terhambat.

28 Hans,Prinsip-prinsip Koperasi dan Undang-undang Koperasi,... h.59. 
Di Kota Malang terdapat Koperasi yang tidak dapat memenuhi syarat pengajuan kredit yang diberikan oleh Bank, Koperasi tersebut adalah Koperasi Karyawan Rumah Sakit Lavallete. Syarat yang tidak dapat dipenuhi oleh Koperasi Karyawan Rumah Sakit Lavallete adalah syarat tentang pengesahan pergantian susunan pengurus baru Koperasi pada sistem. Hal ini membuat kegiatan usaha Koperasi Karyawan Rumah Sakit Lavallete sempat terhambat karena tidak dapat memenuhi syarat pengajuan kredit tersebut.

Syarat tentang pengesahan pergantian susunan pengurus baru telah tercantum pada Pasal 86 ayat (4) Permenkop dan UKM RI Tentang Kewajiban Pengesahan Pengurus Baru Koperasi. Namun, ternyata peraturan tersebut berbenturan dengan Pasal 14 PP RI OSS. Bila terjadi penyimpangan terhadap pengesahan pergantian susunan pengurus baru Koperasi itu disebabkan akibat ketidaktahuan Koperasi atas peraturan tersebut, serta perlakuan perbankan dalam syarat pengajuan kredit yang tidak sama karena ada Bank yang harus menyertakan bukti pengesahan pergantian susunan pengurus baru Koperasi pada sistem dan ada juga yang cukup dengan surat keterangan dari Dinas Koperasi dan UMKM tentang pergantian susunan pengurus baru Koperasi. Namun demikian, penyimpangan terhadap pengesahan pergantian susunan pengurus baru Koperasi harus dicegah dan diminimalisir, oleh karena dampaknya yang lebih banyak negatifnya bagi kelanjutan kegiatan usaha Koperasi yang dimaksud.

Telah dikemukakan bahwa faktor dominan Pelaksanaan Pasal 86 ayat (4) Permenkop dan UKM RI Tentang Kewajiban Pengesahan Pengurus Baru Koperasi di Kota Malang berjalan tidak efektif terutama dikarenakan aspek hukumnya, aparat/ penegak hukumnya dan sarana dan prasarana yang sulit untuk berubah. Koperasi di lingkungan Kota Malang belum mengerti dan paham betapa pentingnya pengesahan pergantian susunan pengurus baru Koperasi dimaksudkan untuk kemudahan Koperasi tersebut dalam menjalankan kegiatan usahanya.

Berdasarkan pertimbangan hukum, tepatlah jika Pasal 86 ayat (4) Permenkop dan UKM RI menetapkan persyaratan Kewajiban Pengesahan Pengurus Baru Koperasi. Untuk itu, guna mencegah terjadinya penyimpangan terhadap kewajiban pengesahan pengurus baru koperasi, perlu usaha-usaha untuk memberikan pemahaman berlakunya peraturan tersebut, yaitu melalui cara sosialisasi dari Dinas Koperasi dan Usaha Kecil Menengah sehingga memunculkan kepahaman dan keseragaman dalam tiap koperasi melaksanakan Pasal 86 ayat (4) Permenkop dan UKM RI Tentang Kewajiban Pengesahan Pengurus Baru Koperasi pada Koperasi di lingkungan Kota Malang. Hal tersebut dapat dilakukan dengan mengirimkan Undang-Undang maupun peraturan lain terbaru tentang koperasi. 
Karena hal tersebut akan memudahkan koperasi untuk mengetahui aturan-aturan baru yang berkaitan dengan Koperasi dan aturan lama yang sudah diganti atau tidak dipakai lagi.

\section{Simpulan}

Lima faktor di atas saling berhubungan erat, sebab menjadi hal pokok dalam ditegakkannya hukum, juga menjadi tolok ukur efektifitas penegakan hukum. Dari kelima faktor penegakan hukum tersebut faktor penegakan hukumnya sendiri merupakan titik sentral. Hal ini akibat oleh UU disusun penegak hukum, penerapannya juga dijalankan oleh penegak hukum dan penegakan hukum sendiri pula merupakan panutan seluruh masyarakat.

Pemaparan di atas menunjukkan bahwa ketentuan tentang pelaksanaan Pasal 86 ayat (4) Permenkop dan UKM RI Tentang Kewajiban Pengesahan Pengurus Baru Koperasi di Kota Malang tidak berjalan efektif ditinjau dari aspek hukumnya, aparat/ penegak hukumnya, sarana dan prasarana, masyarakat dan budayanya. Hal ini mengurangi manfaat dari sistem yang sudah ada dan telah memakan banyak biaya. Padahal sesungguhnya sistem itu dapat dimanfaatkan untuk mengupdate berita terbaru maupun Undang-Undang dan peraturan yang akan semakin mendorong keaktifan kegiatan Koperasi.

Pelaksanaan Pasal 86 ayat (4) Permenkop dan UKM RI Tentang Kewajiban Pengesahan Pengurus Baru Koperasi di Kota Malang berjalan tidak efektif terutama dikarenakan aspek hukumnya, aparat / penegak hukumnya dan sarana dan prasarana yang sulit untuk berubah.

\section{Daftar Pustaka}

\section{Buku}

Djazh, Dahlan. Pengetahuan Koperasi. Jakarta: Balai Pustaka. 1980. Dimyati, Khudzaifah. Teorisasi Hukum. Surakarta: Muhammadiyah University Press. 2004.

Fuady, Munir. Teori-teori Besar Dalam Ilmu Hukum. Jakarta: Kencana. 2013.

Hans. Prinsip-prinsip Koperasi dan Undang-Undang Koperasi. Direktorat Jenderal Koperasi. 1980.

Hendrajogi. Koperasi : Azas-azas Teori dan Praktek. Jakarta: Raja Grafindo Persada. 1997.

Sunarso, Siswantoro. Penegakan Hukum Psikotropika Dalam Kajian Sosiologi 
Hukum. Jakarta: Raja Grafindo Persada. 2010.

Soekanto, Soerjono. Faktor-Faktor Yang Mempengarubi Penegakan Hukum. Jakarta: Rajawali Pers. 2008.

Al-Turky, Abdullah bin Abdul Muhsin. Ushul Mazhab Imam Ahmad. Beirut: Muassasah al-Risalah. 1990.

\section{Artikel}

Fuady, Munir. Politik Hukum Islam di Indonesia Studi Terhadap Legislasi KHI. Jurnal Mimbar Hukum. Nomor 59: 2003.

Musyarrofa Rahmawati, Hanif Nur Widhiyanti, Warkum Sumitro. Efektivitas Pembatasan Usia Perkawinan Berdasarkan Undang-Undang Nomor 1 Tahun 1974 Tentang Perkawinan. JIPPK. Volume ke-3, Nomor 1: 2018.

Retno Mumpuni, Imam Koeswahyono, Rachmad Syafaat, Peran Serta Ondofolo Dalam Ganti Rugi Tanah Untuk Kepentinga Umum Yang Berkeadilan. JIPPK. Volume ke-2, Nomor 1: 2017.

\section{Peraturan Perundang-Undangan}

Keputusan Menteri Negara Koperasi dan Usaha Kecil dan Menengah Nomor 98/ KEP/M.KUKM/IX Tahun 2004 Tentang Notaris Sebagai Pembuat Akta Koperasi

Peraturan Menteri Negara Koperasi dan Usaha Kecil Menengah Nomor 01/ Per/ M.KUKM/I/2006 Tentang Petunjuk Pelaksanaan Pembentukan,Pengesahan Akta Pendirian dan Pembubaran Anggaran Dasar Koperasi

Peraturan Menteri Koperasi dan UKM Republik Indonesia Nomor 09 Tahun 2018 Tentang Penyelenggaraan dan Pembinaan Perkoperasian

Peraturan Pemerintah RI Nomor 24 Tahun 2018 Tentang Pelayaan Perizinan Berusaha Terintegrasi Secara Elektronik

Undang-Undang Nomor 25 Tahun 1992 Tentang Perkoperasian 